\title{
Studies on the Physiological Significance of the Lack of a Pyruvate Dehydrogenase Complex in Hyphomicrobium sp.
}

\author{
By W. HARDER AND A. MATIN \\ Department of Microbiology, University of Groningen, The Netherlands \\ AND MARGARET M. ATTWOOD \\ Department of Microbiology, University of Sheffield, Sheffield $S_{\mathrm{I}}{ }_{2} T N$
}

(Received 28 August 1974; revised I October 1974)

\begin{abstract}
SUMMARY
Hyphomicrobium $\mathrm{x}$ was grown in media containing either methanol or ethanol as a carbon and energy source, with or without additional organic carbon sources. The organism transported pyruvate, malate and succinate into the cells, and incorporated their carbon skeletons into cellular material, but when each of these compounds was added as sole carbon and energy source none supported growth of the organism. Enzymic analysis of crude cell-free extracts failed to detect either a complete pyruvate dehydrogenase complex or an active EI component. Furthermore, oxygen uptake experiments with whole cell suspensions did not show any oxidation of pyruvate, succinate or malate. The distribution of radioactivity amongst the amino acids in hydrolysates of cell protein obtained from organisms grown in the presence of $\left[{ }^{14} \mathrm{C}\right]$ pyruvate, $\left[{ }^{14} \mathrm{C}\right]$ acetate or $\left[{ }^{14} \mathrm{C}\right]$ succinate indicated that the organism is limited in its ability to metabolize pyruvate. Growth in the presence of $\left[{ }^{14} \mathrm{C}\right]$ pyruvate resulted in $93 \%$ of the total radioactivity recovered being associated with amino acids derived directly from pyruvate. In contrast, growth in the presence of $\left[{ }^{14} \mathrm{C}\right]$ acetate or $\left[{ }^{14} \mathrm{C}\right]$ succinate resulted in more-or-less uniform labelling of all biogenic classes of amino acids. These results are consistent with the lack of an active pyruvate dehydrogenase complex which would make it impossible for Hyphomicrobium $\mathrm{x}$ to convert pyruvate into acetyl-CoA and to generate energy from carbon compounds for which the energy metabolism relies on oxidation through tricarboxylic acid (TCA) cycle intermediates.
\end{abstract}

\section{INTRODUCTION}

Strains of the genus Hyphomicrobium, isolated from a wide variety of natural habitats, can utilize only a limited range of compounds as the carbon and energy source for growth. Among the compounds tested, some $\mathrm{C}_{1}$ compounds, the $\mathrm{C}_{2}$ compounds ethanol and acetate, and the $\mathrm{C}_{4}$ compound 3-hydroxybutyrate supported growth, whereas a number of $\mathrm{C}_{3}, \mathrm{C}_{4}$, $\mathrm{C}_{5}$ and $\mathrm{C}_{6}$ compounds were not utilized (Attwood \& Harder, 1973). Preliminary studies with cell-free extracts indicated that the organisms lack an active pyruvate dehydrogenase complex (Harder, Attwood \& Quayle, 1973; Attwood \& Harder, 1974). This suggested that these organisms are unable to generate energy from compounds containing more than two carbon atoms. In the present communication enzymic and isotopic evidence is presented which indicates that these organisms do indeed lack the capacity to channel pyruvate into major energetic and biosynthetic pathways. 


\section{METHODS}

Organisms and growth conditions. Hyphomicrobium strain B522 was obtained from Professor P. Hirsch, University of Kiel, West Germany. Cultures of Hyphomicrobium strains were isolated according to the methods described by Hirsch \& Conti (I964) and Attwood \& Harder (1972) and maintained as previously described (Harder et al. 1973). The organisms were grown at $30^{\circ} \mathrm{C}$ in the standard mineral salts medium (Attwood \& Harder, 1972) with methanol or ethanol $(0.4$ to $0.5 \%, \mathrm{v} / \mathrm{v})$ as carbon and energy source. Organic supplements were added as indicated in the individual experiments. Growth was monitored by measuring the extinction of the culture in a Vitatron UC200 spectrophotometer (Vitatron, Dieren, The Netherlands) at $668 \mathrm{~nm}$ or in an SP 600 spectrophotometer (Pye-Unicam, Cambridge) at $6 \mathrm{I} 0 \mathrm{~nm}$. For enzymic studies, organisms from the mid-exponential phase of growth were harvested by centrifugation at $6500 \mathrm{~g}$ for $20 \mathrm{~min}$ at $4{ }^{\circ} \mathrm{C}$, washed twice with sodiumpotassium phosphate buffer $(2 \mathrm{mM})$ containing magnesium chloride $(5 \mathrm{mM})$ and then either resuspended in the same buffer containing 2-mercaptoethanol $(2 \mathrm{mM})$ or frozen at $-20{ }^{\circ} \mathrm{C}$.

Oxygen uptake measurements. The organisms were grown in the standard medium containing methanol or ethanol $(0.4$ to $0.5 \%, \mathrm{v} / \mathrm{v})$ alone or with different carbon supplements $(0.2 \%, v / v)$. Growth in the presence of the various organic supplements was allowed for at least $\mathrm{I} 6 \mathrm{~h}$. The cells were harvested, washed twice and resuspended in sodium-potassium phosphate buffer $\left(50 \mathrm{~mm}\right.$; $\left.\mathrm{pH} 7{ }^{\circ}\right)$ containing magnesium chloride $(5 \mathrm{~mm})$. Oxygen uptake rates were measured with a Clark-type oxygen electrode (Beckman Instrument Co., London) calibrated so that a full-scale deflexion of the recorder reflected the difference between the oxygen concentration of an air-saturated buffer and a solution of zero oxygen content. Cell suspensions and buffer ( $1.5 \mathrm{ml}$ total volume) were placed in the oxygen electrode vessel and the endogenous rate of oxygen uptake measured for 5 to $10 \mathrm{~min}$ at $30{ }^{\circ} \mathrm{C}$. An organic compound ( $10 \mu \mathrm{l}$ of a $20 \%$ solution) was then injected into the electrode chamber and the new rate of oxygen uptake measured for a further 5 to $\mathrm{I} 0 \mathrm{~min}$.

Preparation of cell-free extracts. The bacteria were disrupted in an ultrasonic disintegrator (M.S.E. Model $60 \mathrm{~W}$ ) and the cell-free extracts obtained as previously described (Harder et al. 1973).

Enzyme assays. All spectrophotometric assays were performed on a Unicam SPr800 recording spectrophotometer at $30{ }^{\circ} \mathrm{C}$. The amounts of enzyme assayed were such that the rates were linear with respect to time for at least $3 \mathrm{~min}$ and were proportional to the amount of extract added. Pyruvate dehydrogenase complex (EC. 6.4.I.I) was assayed for the overall activity by the method of Amarasingham \& Davis (1965). The EI component of the complex was measured spectrophotometrically using ferricyanide as the electron acceptor (Hager \& Kornberg, I96I).

Protein determination. Protein was assayed by the Folin-Ciocalteu method as described by Lowry, Rosebrough, Farr \& Randall (I95I), using bovine serum albumin as the standard.

Uptake of ${ }^{14} \mathrm{C}$-labelled organic compounds. Washed suspensions ( 0.05 to $\left.0.1 \mathrm{mg} \mathrm{dry} \mathrm{wt} / \mathrm{ml}\right)$ prepared from exponentially growing cultures of Hyphomicrobium sp. in media containing methanol or ethanol $(0.5 \%, \mathrm{v} / \mathrm{v})$ as sole carbon source were used to inoculate $(2.0 \%, \mathrm{v} / \mathrm{v}$ inoculum) media containing radioactive methanol ( $5 \mu \mathrm{Ci}$; final concentration $2.5 \mathrm{~mm}$ ) or unlabelled methanol $(2.5 \mathrm{~mm})$ or ethanol $(2.0 \mathrm{~mm})$, supplemented with labelled organic compounds (I० $\mu \mathrm{Ci}$ and $5 \mathrm{mM}$ ). The cultures were incubated and samples ( $1 \circ \mathrm{ml}$ ) were taken at $2 \mathrm{~h}$ intervals for the first $\mathrm{I} 2 \mathrm{~h}$ and then after 24 and $48 \mathrm{~h}$. These were filtered through discs of Whatman $\mathrm{G} / \mathrm{F}$ paper, washed three times with an excess of a solution of unlabelled homologous organic compound (Iо $\mathrm{mM}$ ) and twice with unlabelled methanol or ethanol, 
before drying under an infrared lamp for $30 \mathrm{~min}$. The filters were then placed in vials containing $5.0 \mathrm{ml}$ Bray's (1960) scintillation fluid and counted in a liquid scintillation counter. Medium filtrates ( $\cdot$. I $\mathrm{ml}$ ) were also counted in Bray's solution. The instrument was calibrated using the channels ratio technique and the results corrected for quenching and recorded as $\mu \mathrm{mol}$ substrate taken $\mathrm{up} / \mathrm{mg}$ protein $/ \mathrm{h}$.

The distribution of ${ }^{14} \mathrm{C}$-labelled carbon in cellular amino acids. The method used was similar to that described by Smith, London \& Stanier (1967). Portions ( $10 \mathrm{ml}$ ) of a methanol-grown culture of Hyphomicrobium sp. having a cell density of $0.08 \mathrm{mg} \mathrm{dry} \mathrm{wt} / \mathrm{ml}$ were transferred to $30 \mathrm{ml}$ conical flasks. To each flask a filter-sterilized ${ }^{14} \mathrm{C}$-labelled compound was added ( $20 \mu \mathrm{Ci}$; final concentration $6 \mathrm{mM}$ ), and growth allowed to continue until the cell density reached $0.48 \mathrm{mg} \mathrm{dry} \mathrm{wt} / \mathrm{ml}$ (about $\mathrm{I} 6 \mathrm{~h}$ ). The cells were harvested by centrifugation (I0000 $\mathrm{g}$; $20 \mathrm{~min}, 4^{\circ} \mathrm{C}$ ) and washed twice in $10 \mathrm{ml}$ of a $60 \mathrm{~mm}$ solution of the homologous non-radioactive compound and once in distilled water. The pellet was resuspended in distilled water ( $\mathrm{I} \mathrm{ml}$ ) and transferred to glass vials containing $\mathrm{I} \mathrm{ml}$ of $\mathrm{x} 2 \mathrm{M}-\mathrm{HCl}$. The vials were sealed under vacuum and incubated at $110^{\circ} \mathrm{C}$ for $16 \mathrm{~h}$. The hydrolysates were dried in a stream of warm air $\left(48^{\circ} \mathrm{C}\right)$ and the residues suspended in $2 \mathrm{ml}$ distilled water at $80^{\circ} \mathrm{C}$. The suspension was filtered through Whatman No. I filter paper and the filtrates extracted twice with an equal volume of diethyl ether. The aqueous layer was then dried in warm air and the residue taken up in $0.4 \mathrm{ml}$ of $20 \%(\mathrm{v} / \mathrm{v})$ isopropanol. Five $\mu 1$ of this solution were spotted on cellulose thin-layer plates (DC-Alufolin Cellulose, E. Merck, Darmstadt, West Germany). The plates were developed using two-dimensional chromatography with $n$-butanol-acetone-diethylamine- $\mathrm{H}_{2} \mathrm{O}\left(30: 30: 6: 15\right.$, by vol.) and isopropanol-formic acid- $\mathrm{H}_{2} \mathrm{O}(80: 4: 20$, by vol.), respectively (Stahl, 1962). The plates were then air-dried, sprayed lightly with ninhydrin reagent (Merck) and heated at $80^{\circ} \mathrm{C}$ for $15 \mathrm{~min}$. Individual amino acids were identified by their $R_{F}$ values, determined in control experiments in which known mixtures of amino acids were chromatographed under the conditions described above. The ninhydrin-positive areas were cut out and counted in $5 \mathrm{ml}$ of Triton X-I00-toluene solution described by Patterson \& Greene (1965), using a liquid scintillation counter.

Chemicals. Enzymes and coenzymes were obtained from Boehringer, Mannheim, Germany. Bovine serum albumin was purchased from Armour Pharmaceuticals, Eastbourne. Pyruvate was recrystallized from acetone. Radioactive chemicals were obtained from The Radiochemical Centre, Amersham, Buckinghamshire. Their specific activities were as follows (mCi/mmol): [U_-14 C]pyruvic acid, sodium salt, $10 \cdot 4$; [U-14 $]$ acetic acid, sodium salt, $58 \cdot 5 ;\left[\mathrm{I}, 4^{-14} \mathrm{C}\right]$ succinic acid, $2 \mathrm{I} ;\left[2,3-^{14} \mathrm{C}\right]$ succinic acid, $22 ; \mathrm{L}-\left[\mathrm{U}-{ }^{14} \mathrm{C}\right]$ malic acid, 35 ; $\left[\mathrm{I}, 5^{-14} \mathrm{C}\right]$ citric acid, monohydrate, $18 \cdot 2$; and $\mathrm{D}-\left[\mathrm{U}-{ }^{14} \mathrm{C}\right] \mathrm{glucose}, 30$. The purity of the radioactive compounds was checked before use as described by Matin \& Konings (I973).

\section{RESULTS AND DISCUSSION}

Many strains of the genus Hyphomicrobium have been isolated from a wide range of natural habitats by (i) the method of Attwood \& Harder (1972) using anaerobic incubations with methanol or methylamine as the carbon and energy source and nitrate as the terminal electron acceptor or (ii) by the method of Hirsch \& Conti (1964) using aerobic incubations with no added carbon source. The strains obtained and tested so far can only grow on the same narrow range of carbon compounds (Attwood \& Harder, unpublished results). This could be the result of either a limited ability to transport the substrates into the cell or the lack of one or more key enzymes. 
Table I. Rate of uptake of some organic compounds by Hyphomicrobium $\mathrm{X}$ The organism was grown aerobically in the standard salts medium as described in Methods.

$\begin{array}{ccc}\begin{array}{c}\text { Radioactive } \\ \text { supplement }\end{array} & \begin{array}{c}\text { Methanol-grown } \\ \text { cells }\end{array} & \begin{array}{c}\text { Rthanol-grown } \\ \text { cells }\end{array} \\ \text { Methanol } & 6 \cdot 7 & 0.4 \\ \text { Acetate } & 2 \cdot 0 & 2 \cdot 3 \\ \text { Citrate } & 0 & 0 \\ \text { Glucose } & 0 & 0 \\ \text { Succinate } & \text { I.I } & 0.8 \\ \text { Pyruvate } & 0.4 & 0.3 \\ \text { Malate } & 0.3 & 0.3\end{array}$

\section{Transport of various carbon compounds}

To investigate the possibility that the inability of hyphomicrobia to grow on $\mathrm{C}_{3}$ and higher carbon compounds was due to the failure to transport them across the membrane, Hyphomicrobium $\mathrm{x}$ was grown in methanol or ethanol standard growth medium, supplemented with various ${ }^{14} \mathrm{C}$-labelled compounds. The organisms and the medium were monitored for radioactivity at intervals. The rate of uptake of the various compounds (Table $\mathrm{I}$ ) was linear with time for a period of at least 4 to $5 \mathrm{~h}$ and paralleled the disappearance of radioactivity from the suspending medium. Uptake of methanol and acetate, compounds which can act as sole carbon and energy sources for growth, occurred at a relatively rapid rate. No uptake of the $\mathrm{C}_{6}$ compounds, glucose or citrate, was observed. The rate of uptake of the $\mathrm{C}_{3}$ and $\mathrm{C}_{4}$ compounds, pyruvate, malate and succinate, although lower than that of methanol and acetate was nevertheless quite significant. Uptake of these compounds also occurred when methanol or ethanol was omitted from the incubation medium, although it was only linear for about $2 \mathrm{~h}$ and presumably relied upon endogenous reserves to provide the energy for the transport processes. Similar results were obtained with Hyphomicrobium G and B522. These observations differ from those reported for Methylococcus capsulatus (Dahl, Mehta \& Hoare, 1972) since in this latter organism organic compounds are only incorporated in the presence of methane. Failure of hyphomicrobia to grow on $\mathrm{C}_{3}$ and higher carbon compounds cannot be explained entirely in terms of an inability to transport such compounds into the cell.

\section{Oxidation of various carbon compounds and cell-free studies}

Since pyruvate, malate and succinate can enter the cell, the failure to use these compounds as a carbon and energy source for growth may be the result of a metabolic block. Accordingly, the ability of the organisms to oxidize these compounds was investigated. Hyphomicrobium $\mathrm{X}$ was grown in media containing methanol, ethanol or acetate in the presence or absence of pyruvate, malate or succinate. The rate of oxygen uptake by each washed cell suspension was measured with an oxygen electrode and any stimulation of the endogenous rate upon the addition of an organic compound was recorded. Methanol, ethanol and acetate were oxidized (Table 2), whereas pyruvate, succinate and malate were not. The results also show that during growth on ethanol the ability to oxidize acetate was induced by acetate, malate or succinate and that the ability to oxidize methanol or ethanol was constitutive. Similar results were obtained with Hyphomicrobium $\mathrm{G}$ and $\mathbf{B} 522$.

From previous work on the carbon assimilation pathway during the growth of Hyphomicrobium sp. on methanol, it appeared that the metabolic potential of pyruvate was limited (see Fig. I). These organisms appeared to lack an active pyruvate dehydrogenase complex 
Table 2. Rate of oxygen uptake by cell suspensions of Hyphomicrobium $\mathrm{x}$ grown in the presence of various compounds

Additions to the standard mineral salts medium during growth

Methanol

Ethanol

Acetate

Methanol + ethanol

Methanol+ pyruvate

Methanol+ succinate

Methanol+ malate

Methanol+ acetate

Ethanol + pyruvate

Ethanol+succinate

Ethanol + malate

Ethanol+ acetate
Substrate added to washed suspensions $\left(\mu 1 \mathrm{O}_{2} / \mathrm{mg} \text { protein } / \mathrm{min}\right)^{*}$

Methanol Ethanol Acetate Malate Succinate Pyruvate

$\begin{array}{lll}0.60 & 0.40 & 0 \\ 0.72 & I .20 & 0 \\ 0.73 & - & 0.53 \\ 0.53 & 0.60 & - \\ 0.87 & 0.30 & - \\ \mathrm{I} \cdot 30 & 0.55 & 0 \\ 0.50 & 0.59 & 0.06 \\ 0.94 & 0.64 & 1.60 \\ 0.80 & \mathrm{I} \cdot 70 & - \\ 0.60 & \mathrm{I} \cdot 80 & 0.7 \\ 0.94 & \mathrm{I} \cdot 48 & \mathrm{I} .03 \\ - & 0.55 & 0.58\end{array}$

0
0
0
0
0
0
$0 \cdot I$
0
0
0
0
0

$\begin{array}{ll}0 & 0 \\ 0 & 0 \\ 0 & 0 \\ 0 & 0 \\ 0 & 0 \\ 0 & 0 \\ 0 & 0 \\ 0 & 0 \\ 0 & 0 \\ 0 & 0 \\ 0 & 0 \\ 0 & 0\end{array}$

* Endogenous rate (approx. $0.5 \mu 1 \mathrm{O}_{2} / \mathrm{mg}$ protein $/ \mathrm{min}$ ) subtracted.

-, Not measured.

2-Phosphoglycerate

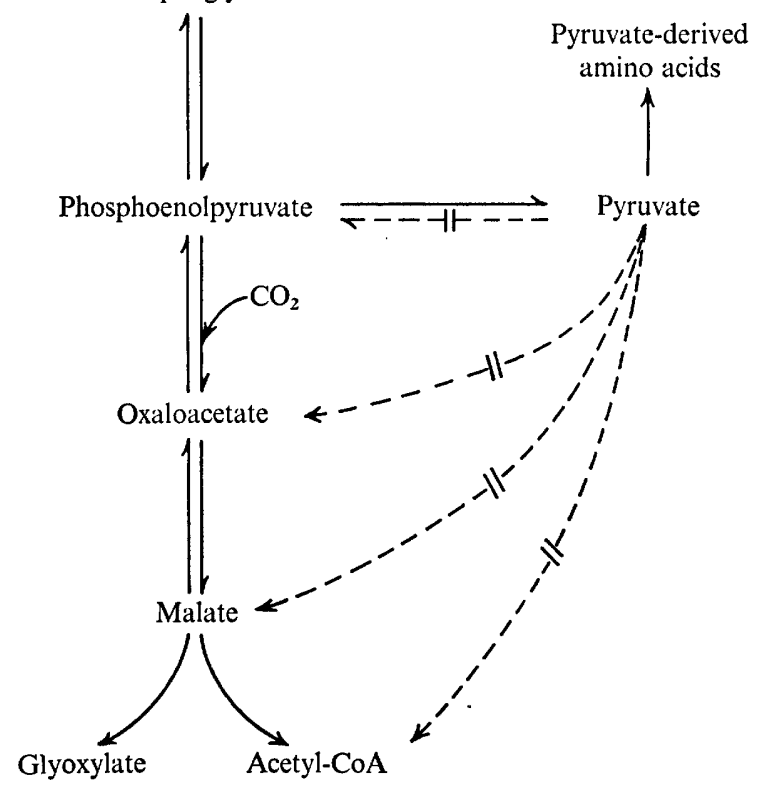

Fig. I. Metabolism of pyruvate in Hyphomicrobium sp.

as well as phosphoenolpyruvate synthase and pyruvate carboxylase (Harder et al. 1973; Attwood \& Harder, I974). If the pyruvate dehydrogenase complex is missing then the organism would be limited in its ability to derive energy for growth on many $C_{3}, C_{4}, C_{5}$ and $\mathrm{C}_{6}$ compounds since it cannot generate the acetyl-CoA required for the TCA cycle. Cell-free extracts were prepared from Hyphomicrobium $\mathrm{x}$ grown in media containing methanol or ethanol as sole source of carbon and energy, with or without the addition of pyruvate, malate or succinate, and assayed for the activity of (i) the overall pyruvate dehydrogenase complex and (ii) the Er component. Both assays were performed over the $\mathrm{pH}$ range 6.5 to 
Table 3. Distribution of radioactive carbon amongst cell amino acids after growth of Hyphomicrobium $\mathrm{x}$ in media supplemented with $\left[{ }^{14} \mathrm{C}\right]$ pyruvate, $\left[{ }^{14} \mathrm{C}\right]$ acetate or $\left[{ }^{14} \mathrm{C}\right]$ succinate

Results are expressed as the percentages of radioactivity recovered from the chromatograms. Total radioactivity recovered was: pyruvate, 15250 d.p.m.; acetate, 25660 d.p.m.; succinate, 530 d.p.m.

Amino acid
Alanine
Leucine+isoleucine
Methionine+ valine
Cysteine + histidine
Glycine
Serine
Phenylalanine
Tyrosine
Tryptophan
Glutamate
Arginine
Aspartate

$\begin{array}{cc}{\left[{ }^{14} \mathrm{C}\right] \text { Pyruvate }} & {\left[{ }^{14} \mathrm{C}\right] \text { Acetate }} \\ 21 \cdot 0 & 10 \cdot 6 \\ 35 \cdot 4 & 13 \cdot 5 \\ 24 \cdot 0 & 7 \cdot 2 \\ 12 \cdot 7 & 7 \cdot 7 \\ 0 \cdot 8 & 6 \cdot 6 \\ 0 \cdot 5 & 2 \cdot 9 \\ I \cdot I & 6 \cdot 9 \\ 0 \cdot 7 & 3 \cdot 0 \\ 0 \cdot 5 & 2 \cdot 2 \\ I \cdot 7 & 19 \cdot 0 \\ I \cdot 3 & 11 \cdot 5 \\ I \cdot 0 & 8 \cdot 9 \\ \text { ND, Not detected. } & \end{array}$

$\left[{ }^{14} \mathrm{C}\right]$ Succinate
$10 \cdot 8$
$7 \cdot 5$
$7 \cdot 2$
$8 \cdot 6$
$7 \cdot 2$
$\mathrm{ND}$
$11 \cdot 0$
$7 \cdot 2$
$2 \cdot 8$
$18 \cdot 0$
$8 \cdot 6$
$13 \cdot 0$

8.5 but no enzyme activity was detected in any extract. Crude extracts of Escherichia coli grown on glucose gave activity with either assay procedure. Furthermore, the overall assay procedure detected activity of the related $\alpha$-ketoglutarate dehydrogenase complex in Hyphomicrobium X. Similar results were obtained with Hyphomicrobium $\mathrm{G}$. Thus no enzyme activity could be detected in cell-free extracts from organisms grown on methanol or ethanol alone, or in media supplemented with pyruvate, malate or succinate as likely inducer compounds. This failure to detect pyruvate oxidation in cell-free extracts may be the result of enzyme inactivation during extract preparation or some unknown enzyme mechanism involving different coenzyme or metal requirements. However, this is unlikely since the oxidation of pyruvate, malate or succinate was not detected in the whole-cell suspension studies (Table 2).

\section{Incorporation of carbon from pyruvate, acetate or succinate in cell amino acids}

If Hyphomicrobium strains are deficient in pyruvate dehydrogenase, pyruvate carboxylase and phosphoenolpyruvate synthase activity, this should be reflected in the pattern of distribution of pyruvate carbon into cell amino acids. Furthermore, the distribution should differ from that obtained when the organism is grown in the presence of $\left[{ }^{14} \mathrm{C}\right]$ acetate or $\left[{ }^{14} \mathrm{C}\right]$ succinate. Therefore organisms were grown for 2.5 generations in methanol media supplemented with $\left[{ }^{14} \mathrm{C}\right]$ pyruvate, $\left[{ }^{14} \mathrm{C}\right]$ acetate, or $\left[{ }^{14} \mathrm{C}\right]$ succinate and analysed for the distribution of radioactivity in cell amino acids (Table 3). In the interpretation of these data, it is assumed that the pathways of amino acid biosynthesis in Hyphomicrobium sp. are similar to those reported for other organisms.

The method used resolved cell hydrolysates into nine individual amino acids and three double amino acid spots. Very few amino acids became labelled after growth in the presence of $\left[{ }^{14} \mathrm{C}\right]$ pyruvate. Among the amino acids which were completely resolved, only alanine, which is derived directly from pyruvate, contained significant radioactivity; little or no radioactivity was found in amino acids derived from phosphoenolpyruvate (phenylalanine, tyrosine, tryptophan, serine, glycine), oxaloacetate (aspartate), or $\alpha$-ketoglutarate (glutamate). All the double amino acid spots contained high amounts of radioactivity. One of the component amino acids of each of these spots is known to be derived directly from pyruvate 
(i.e. leucine, valine and cysteine). The other component is derived from aspartate in the case of isoleucine and methionine, or phosphoenolpyruvate in the case of histidine. Since aspartate itself contained little radioactivity and none of the other amino acids derived from phosphoenolpyruvate showed significant amounts of radioactivity, it seems likely that the radioactivity in the double amino acid spots is due primarily to the component derived from pyruvate. If so, $93 \%$ of the total radioactivity recovered from the chromatogram is present in amino acids for which pyruvate is the direct precursor. In contrast, cells grown in the presence of $\left[{ }^{14} \mathrm{C}\right]$ acetate showed radioactivity in all biogenic classes of amino acids. Amino acids derived directly from pyruvate accounted for only $39 \%$ of the total radioactivity recovered and the largest amount of radioactivity was found in glutamate. Similarly, cells grown in the presence of $\left[{ }^{14} \mathrm{C}\right]$ succinate showed radioactivity in all biogenic classes of amino acids, although the total contribution of succinate carbon to amino acid biosynthesis was relatively small. The radioactivity was associated predominantly with glutamate and aspartate. From these results it is apparent that, in contrast to acetate and succinate, this organism can make only restricted use of pyruvate. Similar results were obtained with Hyphomicrobium strains $\mathrm{G}$ and 522B. Control experiments with $E$. coli showed a distribution of radioactivity in all biogenic classes of amino acids after growth in the presence of $\left[{ }^{14} \mathrm{C}\right]-$ acetate, $\left[{ }^{14} \mathrm{C}\right]$ succinate or $\left[{ }^{14} \mathrm{C}\right]$ pyruvate. These results are consistent with known amino acid biosynthetic pathways in micro-organisms and carbon assimilation pathways in Hyphomicrobium sp. grown on methanol, ethanol or acetate (Fig. r; Harder et al. 1973; Attwood \& Harder, 1974). Thus when $\mathrm{C}_{3}$ and $\mathrm{C}_{4}$ compounds are present as the sole source of carbon and energy, they are unable to support the growth of these organisms, and this appears to be due to the inability of the organisms to generate the acetyl-CoA required by the TCA cycle. This failure to oxidize pyruvate appears to be widespread among hyphomicrobia, but is not common to all methanol-utilizing organisms since Pseudomonas AMr has been shown to contain pyruvate dehydrogenase activity when growing on methanol $(0.04 \mu \mathrm{mol} /$ $\mathrm{mg}$ protein $/ \mathrm{min})$. This is reflected in the ability of the organism to grow on succinate and pyruvate as sole carbon and energy source (Salem, Wagner, Hacking \& Quayle, 1973).

It is not clear why the inability to channel pyruvate into major pathways of intermediary metabolism has persisted in Hyphomicrobium sp. during the course of evolution. Since these organisms are ubiquitous (Hirsch \& Conti, I964; Attwood \& Harder, 1972), it must be assumed that in their natural habitat the loss of this potential is of no serious consequence. The situation is reminiscent of the lack of $\alpha$-ketoglutarate dehydrogenase in obligate chemolithotrophs (Smith et al. 1967; Kuenen \& Veldkamp, 1973). Another point of similarity between Hyphomicrobium sp. and the obligate chemolithotrophs is that both groups of organisms show absolute dependence on special energy sources. In their presence they are able to assimilate various compounds and use them as a carbon source. This is made evident by an increased cell yield, when such compounds are supplied under energy limitation in continuous culture (J. Meiberg and W. Harder, unpublished; Kuenen \& Veldkamp, I973).

We thank Mr D. J. Trott for technical assistance. 


\section{REFERENCES}

Amarasingham, C. R. \& Davis, B. D. (1965). Regulation of $\alpha$-keto glutamate dehydrogenase formation in Escherichia coli. Journal of Biological Chemistry 240, 3664-3668.

ATTWOOD, M. M. \& HARDER, W. (1972). A rapid and specific enrichment procedure for Hyphomicrobium sp. Antonie van Leeuwenhoek 38, 369-378.

ATTwOod, M. M. \& HARDER, W. (1973). The metabolism of organic carbon compounds in Hyphomicrobia: metabolism of $\mathrm{C}_{2}$ compounds. Antonie van Leeuwenhoek 39, 357.

ATTwOOD, M. M. \& HARDER, W. (1974). The oxidation and assimilation of $\mathrm{C}_{2}$ compounds by Hyphomicrobium sp. Journal of General Microbiology 84, 350-356.

Bray, G. A. (1960). A simple efficient liquid scintillator for counting aqueous solutions in a liquid scintillation counter. Analytical Biochemistry I, 279-285.

DahL, J. S., MehtA, R. J. \& HoARE, D. S. (1972). New obligate methylotroph. Journal of Bacteriology Iog, 9I6-92I.

HAGER, L. P. \& KoRNBERG, H. L. (196I). On the mechanism of $\alpha$-oxoglutarate oxidation in Escherichia coli. Biochemical Journal 78, I 55-I63.

Harder, W., AtTwood, M. M. \& QuaYle, J. R. (1973). Methanol assimilation by Hyphomicrobium sp. Journal of General Microbiology 76, I55-163.

HIRSCH, P. \& CoNTI, C. F. (I964). Biology of budding bacteria. II. Growth and nutrition of Hyphomicrobium spp. Archiv für Mikrobiologie 48, 358-367.

KUENEN, J. G. \& VeLDKAMP, H. (I973). Effect of organic compounds on growth of chemostat cultures of Thiomicrospira pelophila, Thiobacillus thioparus and Thiobacillus neapolitanus. Archiv für Mikrobiologie 94, 173-190.

Lowry, O. H., Rosebrough, N. J., Farr, A. L. \& Randall, R. J. (I95I). Protein measurement with the Folin phenol reagent. Journal of Biological Chemistry 193, 265-275.

Matin, A. \& Konings, W. N. (1973). Transport of lactate and succinate by membrane vesicles of Escherichia coli, Bacillus subtilis and a Pseudomonas species. European Journal of Biochemistry 34, 58-67.

Patterson, M. S. \& Greene, R. C. (1965). Measurement of low energy beta-emitters in aqueous solution by liquid scintillation counting of emulsions. Analytical Chemistry 37, 854-857.

Salem, A. R., Wagner, C., Hacking, A. J. \& Quayle, J. R. (1973). The metabolism of lactate and pyruvate by Pseudomonas AMI. Journal of General Microbiology 76, 375-388.

Smith, A. J., London, J. \& STANier, R. Y. (1967). Biochemical basis of obligate autotrophy in blue-green algae and thiobacilli. Journal of Bacteriology 94, 972-983.

STAHL, E. (1962). Dünnschicht-Chromatographie, pp. 739-746. Berlin: Springer Verlag. 